\title{
CENEVRE'DE BİR JÖN TÜRK MIZAH GAZETESİ: TOKMAK
}

\section{Servet TIKKEN*}

$\ddot{\mathbf{O} z}$

Osmanlı modernleşmesinin öncü unsurları arasında yer alan; sanat, edebiyat ve siyasal düşünce akımlarının gelişmesinde etkili olan gazete, II. Abdülhamit dönemindeki siyasal gelişmelerle birlikte dikkat çekici bir işlev üstlenir. Meşrutiyet yanlılarının gazete aracılığıyla Osmanlı yönetimine karşı mücadelelerini sürdürdüğü bu yıllarda, II. Abdülhamit de muhalif gazetelere karşı çeşitli tedbirler alır. Osmanlı sultanı, bu yöndeki yaptırımlarından birini de mizah basınını yurt içinde yasaklamasıyla gerçekleştirir. Bunun üzerine mizah basını yurt dışına yönelir ve II. Abdülhamit'e karşı son derece sert bir muhalefete girişir. Cenevre'de Jön Türklerin radikal kanadının yayınlarından biri olan Tokmak gazetesi de Osmanlı hükûmeti ile Jön Türkler arasındaki mücadeleyi yansıtan ve mizah gazeteciliğinin etkili bir muhalefet aracına dönüştüğünü gösteren bir örnektir.

Anahtar Sözcükler: Mizah Gazetesi, Cenevre, Jön Türk, II. Abdülhamit, Tokmak.

\section{A YOUNG TURKS' HUMOR NEWSPAPER IN GENEVA: TOKMAK}

Newspaper which takes part an efficient role in the art, literature and political movements of thought remains one of the precursor of the Ottoman modernization, assumes an attractive function with the political developments in Abdülhamit II Age. Abdülhamit II also takes different measures against the dissident newspapers when constitutional monarchy followers maintain their campaign towards to the Ottoman administration by newspapers in these years. Ottoman sultan realizes one of these measures by restricting humor press in domestic. In response, humor press tends towards to foreign and undertakes an extreme opposition to Abdülhamit II. Tokmak newspaper which is one of the publications of Young Turks radical followers' is an outstanding example humor journalism how it can turn into an efficient opposition tool by reflecting the struggle between Young Turks and Ottoman administration.

Keywords: Humor Newspaper, Geneva, Young Turks, Abdülhamit II, Tokmak.

\section{Abdülhamit Dönemi Mizah Gazeteciliği:}

Tanzimat sonrası Türk düşünce ve edebiyatının yenileşmesine katkı sağlayan türlerin başında gazete gelir. 19. yüzylldan itibaren gündeme yerleşmeye başlayan gazete, yeni düşünce akımlarının tanınma ve yayılmasındaki etkinliğinin yanı sıra edebiyatın gerek biçim gerekse içerik açısından çeşitlilik kazanıp gelişmesine de öncülük eder. Bu yönüyle hem Türk siyasal düşüncesinin hem de Türk edebiyatının gelişmesinde etkin bir rol oynar.

\footnotetext{
*Yrd. Doç. Dr.; Atatürk Üniversitesi Edebiyat Fakültesi Türk Dili ve Edebiyatı Bölümü, servettiken@ @otmail.com.
} 
Edebiyatla çok sıkı bir ilişki içinde olan gazete, 19. yüzyılın ikinci yarısından itibaren Osmanlı'da öğretici ve yönlendirici özellikleriyle ayırt edici bir işlev üstlenir. Ahmet Hamdi Tanpınar'ın tespitiyle, hiçbir yerde gazete bizdeki role benzer bir rol oynamamıştır. Bizde bütün işaretler gazeteden gelir. Kalabalık onun etrafında kurulur. Okumayı o yayar. Mekteplerin uzak gelecek için hazırladığ ${ }_{1}$ ocağı o tutuşturur (Tanpınar, 2006, s. 231). Böylelikle yenileşme döneminde gazete aracılığıyla toplumsal duyarlılıklar oluşturulmaya çalış1lır ve siyasal yaklaşımlarla birlikte sanat ve edebiyat geniş kitlelere sunulur.

Osmanlı'da gazete, 1831 y1lında II. Mahmut'un girişimleriyle Takvîm-i Vekâyi adlı resmî gazetenin yayımlanmasıyla başlar. 1828'de Mısır'da yayımlanan Arapça ve Türkçe Vekâyi-i Mısrıyye'den ve İzmir'de yayımlanan Fransızca gazetelerin Avrupa'da uyandırdığı yankılardan etkilenen II. Mahmut, reformcu kimliğiyle toplumu Batı yönünde değiştirmek ve dönüştürmek için gazeteyi bir modernleşme aracı olarak görür (Budak, 2014, s. 191). Gazeteye yüklenen bu görev sonucu Osmanlı'da gazetenin ortaya çıkışı ve yaygınlaşması ile siyasal alandaki modernleşme çabaları eş zamanlı bir süreç izler. Bu noktada Takvîm-i Vekâyi'nin yayımlanması, yenilikçi padişahın siyasal tutumuyla örtüşen bir adım olarak dikkat çeker.

Türk gazeteciliğinin ilk devrini, resmî bir gazete olan Takvîm-i Vekâyi ile yarı resmî Ceride-i Havadis oluşturur. İkinci devrini ise Tercüman-ı Ahval ve Tasvir-i Efkâr başlatır (Şapolyo, 1971, s. 120). Agâh Efendi ve Şinasi'nin çıkardıkları gazeteler, özel Türkçe gazeteciliğin ilk deneyimleri olma özelliğini gösterir. Böylelikle gazete artık devlet yönetiminin amaçladığı yenilikleri devlet eliyle aktarma işlevinden uzaklaşır ve giderek muhalif düşüncelerin de ifade imkânı bulduğu zemine dönüşür. Özellikle 1870'lerden itibaren de etkili bir muhalefet aracı olur.

Yenilik taraftarı olan ve zamanla eleştiri oklarını hükûmete çeviren gazeteler, mizahı da bu yönde etkili bir yöntem olarak kullanırlar. Bu doğrultuda ilk Türkçe mizah gazetesi, Ermeni asıllı Filip Efendi tarafından yayımlanan Terakkî gazetesinin dört sayfalık "eğlenceye dair gazetedir” ibaresiyle 1870 'de çıkarmaya başladığ 1 eki olur. Kısa bir süre sonra Rum asıllı Teodor Kasap'ın daha önce Fransızca ve Rumca olan Diyojen'i Türkçe yayımlamasıyla müstakil ilk mizah gazetesi yayına başlar (Ulusoy Nalcıoğlu, 2013, s. 323-324). Mizah gazeteciliğinin Osmanlı yayın hayatına girişi beraberinde tartışmaları, yayın durdurmalarını ve gazete kapatma cezalarını getirir. Öyle ki, mizahın sivri dili ve sert üslubu zamanla sarayı rahatsız edecek, böylece mizahın iktidarla savaşı şiddetlenerek sürecektir. 
I. Abdülaziz'in iktidarının son yıllarında gelişme imkânı bulan mizah gazeteciliği, devlet yönetimine çeşitli eleştiriler getirse de özellikle Sultan/Halife'ye karşı büyük ölçüde saygılı bir dil kullanır. Dönemin mizah basınında, I. Abdülaziz'e bir kere yer verilmesinin dışında -ki onun da yabancı kökenli olduğu ileri sürülür- Osmanlı hükümdarlarının karikatürlere konu edilmesine hiç rastlanılmaz (Koloğlu, 2005, s. 93). Ancak II. Abdülhamit'in saltanat yıllarında tam tersi bir durum olur. Saray ile mizah basını arasındaki mücadele doruğa ulaştığ gibi, Osmanlı sultanı, mizah yazar ve çizerlerinin de hedefi hâline gelir. Bununla birlikte Osmanlı basın tarihinde mizaha yönelik en sert ve kapsamlı baskı da bu devrede uygulamaya konulur.

Aslında Osmanlı hükûmeti ile mizah basını arasındaki gerilim II. Abdülhamit'in tahta çıkışının öncesinde başlar. Belli sürelerde yayın tatili ya da kapatma cezalarıyla dizginlenen mizah basını için ilk genel uyarı Ocak 1876 'da olur ve mizah gazetelerinde yer alacak resimlerin (karikatürlerin) önceden Matbuat İdaresine bildirilmesi ve "basıla" diye işaret edilmedikçe yayımlanamayacağı Ceride-i Havadis'te ilan edilir (Ulusoy Nalcıoğlu, 2013, s. 365). I. Abdülaziz'in saltanat yıllarının son aylarına rastlayan bu tedbir kararı, hükûmetin mizahî yazıların yanı sıra karikatürlerden de rahatsız olduğunu gösterir. Mizah basınına yönelik uygulamaya konulan bu sıkı denetim, II. Abdülhamit tarafından daha sonra gerçekleştirilecek yaptırımların da habercisidir.

Osmanlı hükûmeti ve mizah basını arasında gerilen ipler, II. Abdülhamit'in iktidara gelmesinden kısa bir süre sonra bütünüyle kopar. 1877 y1lında Meclise sunulan bir kanun tasarısıyla mizah gazete ve dergilerinin yayımlanması yasaklanır. Mecliste "mizah soytarılık mıdır?" tartışmalarıyla iz bırakan bu yasak, meclisin kabul etmemesine rağmen padişahın iradesiyle gerçekleşir (Altın, 2014, s. 42). Bu yaptııı, mizah basınına yönelik en kapsamlı tedbir olarak basın tarihinde yerini alır. Daha önce mizah dergi ve gazetelerine ferdî olarak uygulanan kapatma kararı, bu kez topyekûn bir hâl alarak yayınların bütününü kapsar.

II. Abdülhamit döneminde güncel politikalara dokunmamak ve devletin resmî tezlerini sorgulamamak kaydıyla mizaha izin verilir. Hüseyin Rahmi'nin yaşadığı dönemin toplumsal sorunlarına değindiği eserleri ve Ahmet Rasim'in belli başlı gazete ve dergilerde yazdığı politik vurgular içermeyen yazıları bu dönemin yasaklanmayan mizahına örnektir (Apaydın, 2006, s. 330-331). Ancak siyasal mücadelenin şiddetlenmesi ve muhaliflerin yurt dışına kaçışları ile birlikte gazetelerde oluşan politik tavır sonucu, özellikle mizah basını daha keskin bir dil kullanmaya başlar. Böylelikle II. Abdülhamit döneminde mizah ikiye ayrılır: Birincisi, hükûmet 
politikalarını sorgulamayan yasal mizah; ikincisi ise yurt dışında yayımlanan ve gizlice ülkeye sokulan yasa dışı mizah.

Muhaliflerin yurt dışına çıktıklarında barındığı, gazete ve dergi yayımladığg yerler Paris, Kahire, Londra ve Cenevre olur. II. Abdülhamit döneminde diğer gazetelerin yanında yurt dışındaki mizah basını Beberuhi, Davul, Dolap, Tokmak ve Lak Lak gibi yayınlarla sert bir muhalefete girişir. Sayfalarında devlet yönetimine karşı ağır eleştirilere yer vererek II. Abdülhamit'e karikatürlerle ölçüsüzce hakaret eder. Bu sebeple sürgündeki mizah gazeteleri Osmanlı yönetiminin nazarında "hezeyanname", sahibi ise "erbab-1 fesad" arasında sayılır (Altın, 2014, s. 47). Osmanlı hükûmeti yurt dışında faaliyet gösteren ve kaçak yollara yurda sokulup elden ele dolaşan mizah gazetelerinin yayımının durdurulması ve ülkeye girişinin engellemesi için büyük çaba sarf eder.

II. Abdülhamit dönemi, mizah basınına en kapsamlı sansürün uygulandığı ve bununla birlikte yurt dışındaki mizahın ölçüsüzce sertleştiği yıllar olarak tarihteki yerini alır.

\section{Cenevre’de Jön Türkler ve Mizah Gazeteciliği:}

19. yüzyılın ortalarından 20. yüzyılın ortalarına kadar Doğu Avrupa, Rusya, Balkanlar ve Osmanlı coğrafyasından birçok siyasi sı̆̆ınmacının ya da öğrencinin ilgisini çeken İsviçre (Kieser, 2008, s. 11), bu dönemde çeşitli sebeplerle devlet yönetimine cephe alan Osmanlı muhalefetinin gözde adreslerinden biri olur. Yurt dışında basın yayın yoluyla faaliyet imkânı arayan muhalifler, İsviçre'nin batısında yer alan Cenevre kantonunda ihtilalci fikirlerini ifade etme ve İstanbul'a duyurma firsatı bulurlar.

II. Abdülhamit döneminde Cenevre'ye yerleşen Meşrutiyet taraftarları hem siyasal olarak örgütlenirler hem de basın yayın aracılığıyla etkili olmaya çalışırlar. Yıldız Sarayı ile arası açılanların Cenevre'ye yönelmesi, kuşkusuz bu bölgenin onlara sunduğu imkânlarla ilintilidir. Liberal bir yönetime sahip olan Cenevre'nin iktidar karşıtlarına özgürlükçü bir ortam sunması, Batı ile ilk temasların kurulduğu Fransa'ya oldukça yakın ve Fransızca konuşulan bir bölge olması, muhalif Osmanlı aydınını buraya yaklaştıran etkenler arasındadır.

Osmanlı aydınının Cenevre'deki yayıncılık deneyimi, II. Abdülhamit dönemi öncesinde başlar. Cenevre'de ilk kez, yayımladıkları Hürriyet gazetesi ile Yeni Osmanlılar seslerini duyurur. Önce Londra'da yayımlanan, daha sonra Ziya Bey tarafından Cenevre'ye taşınan Hürriyet, 3 Nisan 1870'ten itibaren 89. sayısından 100. sayısına kadar yayın hayatını burada sürdürür (Bilgegil, 1970, s. 510). Ziya Bey'in Cenevre'de Hürriyet gazetesini çıkardığı sırada 
kısa ömürlü İnkllâb gazetesi de, Hüseyin Paşa ve Mehmed Bey tarafından yayımlanmaya başlar (Bilgegil, 1976, s. 278). Böylelikle II. Abdülhamit döneminde birçok Türkçe gazete ve dergiye ev sahipliği yapacak olan Cenevre'de yayıncılık noktasında ilk adımlar atılmış olur. Yeni Osmanlılar'ın söz konusu deneyimleri, Cenevre'de zaman içinde güçlenen Osmanlı muhalif gazeteciliğinin öncü örnekleri olarak basın tarihindeki yerini alır.

Başlangıçta Yeni Osmanlılar adıyla örgütlenen Abdülmecit döneminin Batılılaşma yanlısı Tanzimat ricalinden birkaç genç, daha sonra Mustafa Fazıl Paşa'nın desteğiyle Avrupa'ya taşınır ve burada zamanla Jön Türk adıyla anılmaya başlar. Aynı düşünce çizgisinde bulunmayan ancak ortak paydaları II. Abdülhamit'e muhalefet olan Jön Türkler, yurt dışında basın yayın aracıllğıyla verdikleri siyasal mücadeleyle dikkat çekerler. II. Abdülhamit döneminde sürgün edildikleri ya da firar ettikleri birçok yerde gazetecilik faaliyetine girişen Jön Türklerin Kahire ve Paris'le birlikte etkili olduğu merkezlerden biri de Cenevre'dir.

19. yüzyılın sonlarına doğru Cenevre'de, Osmanlı hükûmetinin yakından takip ettiği siyasal gelişmeler ortaya çıkar. 1896'da Tunalı Hilmi Bey Osmanlı İhtilal Fırkası'nı kurar (Mardin, 2002 s. 141). Bir y1l sonra 1897'de İttihat ve Terakki faaliyet merkezi Paris'ten, yeni bir çizgiye yöneleceği, şiddet yöntemlerini benimseyerek II. Abdülhamit'e suikast planları düzenleyeceği Cenevre'ye taşınır (Akşin, 2014, s. 68). Tunalı Hilmi’nin İslamî bir söylemle Osmanlı sultanına karşı yaptığı şiddet çağrıları ile İttihat ve Terakki Cenevre grubunun eylemci tutumu, burada oldukça sert bir muhalefetin oluşmasına zemin hazırlar. Kuşkusuz Cenevre'de örgütlenen Jön Türklerin II. Abdülhamit'e karşı en önemli silahı yine basın olur.

Jön Türklerin siyasal karargâhı Cenevre'de aktif Jön Türklerden olan Emrullah Efendi ile Tevfik Nevzâd'ın 1894 yılında yayımladığı Hizmet gazetesi, ilk Jön Türk yayını olarak kabul edilir (Göçmen, 1995, s. 143). Ardından Cenevre'de İttihat ve Terakki’nin kurduğu etkinliklerle eş zamanlı olarak Mizan, Osmanl, Intikam, Ezan ve Darbe gibi gazetelerle varlığını sürdüren Jön Türk basını, Meşrutiyet yanlısı düşünceler etrafinda II. Abdülhamit'i hedef alan yayınlar yapar. Cenevre'deki muhalif Osmanlı basınında da, İttihat ve Terakki'nin siyasal anlamdaki şiddete yönelen eylemci ve ihtilalci tavrı gözlemlenir. Dönemin muhalif gazete ve dergilerine yansıyan sert üslup Intikam, Darbe ve Tokmak gibi gazetelerin adlarında da kendini belli eder.

Gazeteyi siyasal bir güç aracı olarak kullanan Cenevre'deki Jön Türkler, çıkardıkları mizah gazeteleriyle de etkili olmaya çalışırlar. Cenevre Jön Türk mizah basınını Beberuhı̂ ve Tokmak adlı iki kısa ömürlü gazete temsil eder. Muhalif basının yayın çizgisine koşut olarak 
çıkarılan mizah gazetelerinin de hedefinde yine II. Abdülhamit'in şahsı ve yönetimi vardır. $\mathrm{Bu}$ doğrultuda Cenevre Jön Türklerinin "intikam”c1 ve "darbe”ci düşünceleri söz konusu mizah gazetelerinin ana fikrini oluşturur.

Cenevre'de radikal kanadın elinde bulunan Beberuhî ve Tokmak son derece sert bir muhalefetin sözcülüğünü yapar. Şiddet fantezileriyle dolu bu gazetelerde açıktan açı̆̆a şiddet çağrısı yapılır (Kieser, 2008, s. 89-90). Mizahi unsurlardan çok, hakaret ve nefretin hâkim olduğu bu gazeteler, yayımladıkları karikatürlerde de son derece ölçüsüzdür. Karikatürlerin hedefinde yer alan II. Abdülhamit'in oldukça kötü benzetmelerle çizilmektedir.
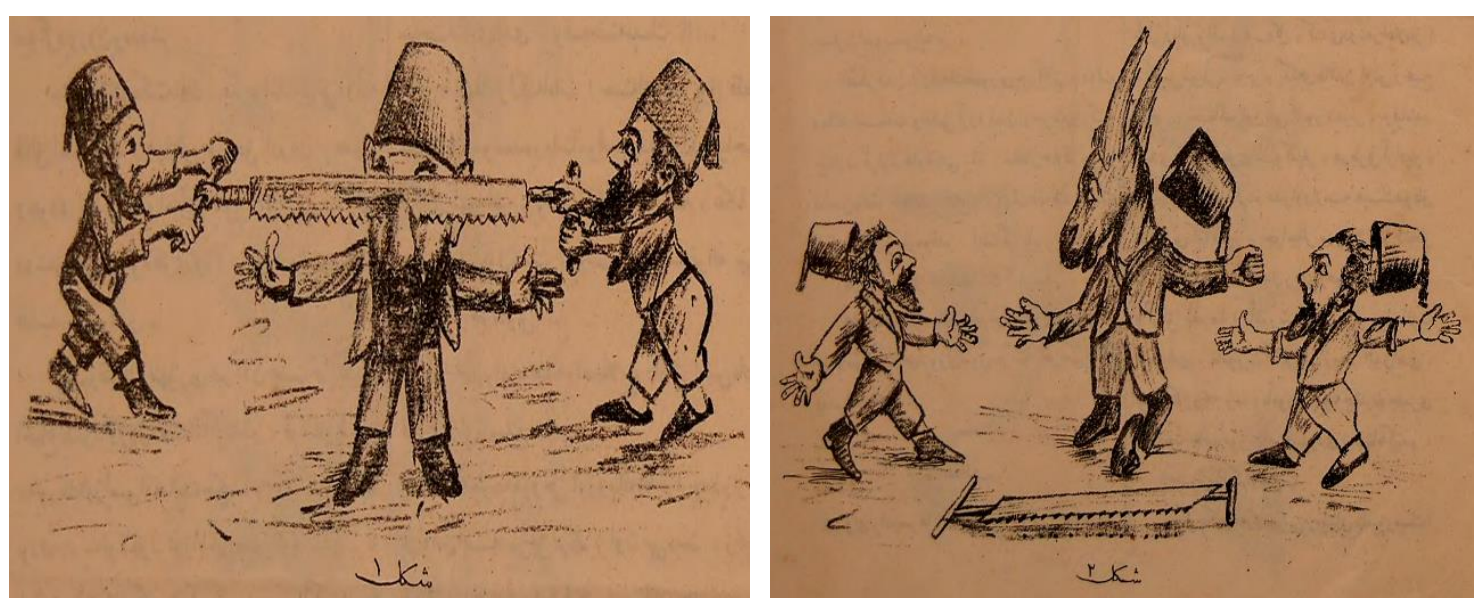

(Beberuhi, Sayı 2, 1 Mart 1898)

Cenevre'deki mizah basınının içeriği kuşkusuz Yıldız Sarayı'nı rahatsız eder ve Osmanlı yönetimi, gazetelerin kapatılması için mücadele eder. Hükûmet eliyle mizah yayınlarının engellenmesi için yapılan girişimler, beraberinde siyasal pazarlıkları getirir. $\mathrm{Bu}$ noktada Cenevre'de yayımlanan mizah gazetesi Tokmak, hem dönem basınının mizah içeriğini hem de mizahın yol açtığı siyasal pazarlıkları örneklemesi bakımından oldukça önemlidir.

\section{Mizahın Siyasal Pazarlık Aracına Dönüşmesi: Tokmak Gazetesi}

Cenevre Jön Türklerinin mizah yayını Tokmak gazetesinin ilk sayısı 1 Mart 1901 tarihinde yayımlanır. "İki haftada bir fakat pir iner" sloganıyla çıkacağı ilan edilen gazetenin ilk üç sayısı iki hafta arayla, dördüncü ve beşinci sayısı ise gecikmeli olarak yayımlanır. Kısa ömürlü olan ve sadece beş sayı yayımlanabilen gazetenin son sayısındaki tarih ise 15 Haziran 1901 'dir. İlk sayfalarının başında adresinin "Case Montblanch, No: 4515 Genéve (Suise)” diye belirtildiği gazetenin her sayısının sonunda "Cenevre'de İntikâm matbaasında tab' olunmuştur" bilgisine yer verilir. 
Tokmak, Cenevre'de yayımlanan bir başka gazete olan Intikam gazetesinin çevresinde bulunan Ali Fahri, Ali Galib, Hamid Hüsnü ve Asaf Nazmi gibi Jön Türkler tarafından çıkarılır (Göçmen, 1995, s. 240). Ayrıca gazetenin yayımlanmasında Jön Türklere ve Ermenilere sempati besleyen İsviçreli yardımcıların katkılarının olduğundan da söz edilir. Gazetenin sorumlusunun Cenevreli matbaacı Joseph Demierre olduğu ve her sayıda yer alan II. Abdülhamit karikatürünün de bir başka İsviçreli A. Gautschi'nin kaleminden çıktığı, gazeteyle ilgili verilen bilgiler arasındadır (Kieser, 2008, s. 91-92).

Tokmak gazetesinin çıkışı ülke dışındaki Jön Türkler arasında meydana gelen bir ayrılığın sonrasında gerçekleşir. Damad Mahmud Paşa'nın Osmanlı gazetesini denetimine almasıyla birlikte gelişen olayların ardından Tunalı Hilmi Bey, Cenevre'de icraatçı grubu örgütlemesi için Mısır'da önemli görevler yapmış olan Ali Fahri’yi ikna eder. Böylece Cenevre'de "İntikamcı Yeni Osmanlılar Cemiyeti” ortaya çıkmış olur. Örgüt önce Íntikâm'1 ardından Tokmak gazetesini yayımlamaya başlar (Hanioğlu, 1989, s. 377). İcraatçı bir örgütün yayın organı olma özelliğiyle Tokmak gazetesi bu doğrultuda şiddet içerikli ve ihtilale zemin hazırlayan bir yayın politikası izler.

Muhaliflerin mizah gazetesi Tokmak yayın hayatına, ilk sayısında Osmanlı sultanını hedef alan ifadelerle başlar. Gazetenin amacının açıklandığı bu sözlerle daha önceki nasihatlerini bir türlü anlamayan II. Abdülhamit'in bir kez daha uyarılacağı dile getirilir:

—Ziyâ Pâşâ merhum:

"Nush ile uslanmayanı etmeli tekdîr

Tekdîr ile uslanmayanın hakkı kötektir."

demiş, ne büyük isâbet etmiş.

Yıldız kuklasının artık arsızlığı, yüzsüzlüğü taştı, aştı, nasîhat, tekdîr, hatta bazı bazı kötek dahi kâr etmez oldu. Düşündük, taşındık: Ya o kafa inâdından geçer, ya parçaları!!.. dedik (Tokmak)lamaya karar verdik.

Bakalım belki "dokuz yumruk bir nasîhat yerine geçer!."

—Öyle ama o nasîhati yuvada almış.

—Evet, bu doğru fazla olarak da hasseten beş senedir aldığı nasîhatler hesâba, kitâba gelmez, bunların hiç biri, ama hiç biri kâr etmedi. Çâre yok: şu tılsımlı (Tokmak)la yoklamalı! Ya o inâdından geçer, ya parçalarız vesselâm!. 
—Fakat bırakın cânım şu miskîni! Baksanıza cânı burnuna firlamış telâş içinde!.. Kıvranıp duruyor.

—E ne yapalım? Dünya da bilir ki biz, o başı başımızda gezdirmek isterdik. O bizim sâfiyetimizi, hürmetimizi meskenet bildi. Ezdikçe ezdi. Ezdikçe ezdi. Hepimizi aç, çıplak bıraktı. Varımızı yoğumuzu çaldı. Mülkümüzü, bucağımızı, düşmana sattı. Dalkavuklara yedirdi. Çoluğumuzu, çocuğumuzu, babalarımızı, kardeşlerimizi işkenceler altında öldürdü. Denizlerde boğdu, sürgünlerde çürüttü. Hâlâ da öldürmüyor mu, boğmuyor mu, çürütmüyor mu?

Bırak şu Nemrûd'u bırak! Onun müstehakı tokmak altında kıvranmaktır. (Sayı 1, 1 Mart 1901)

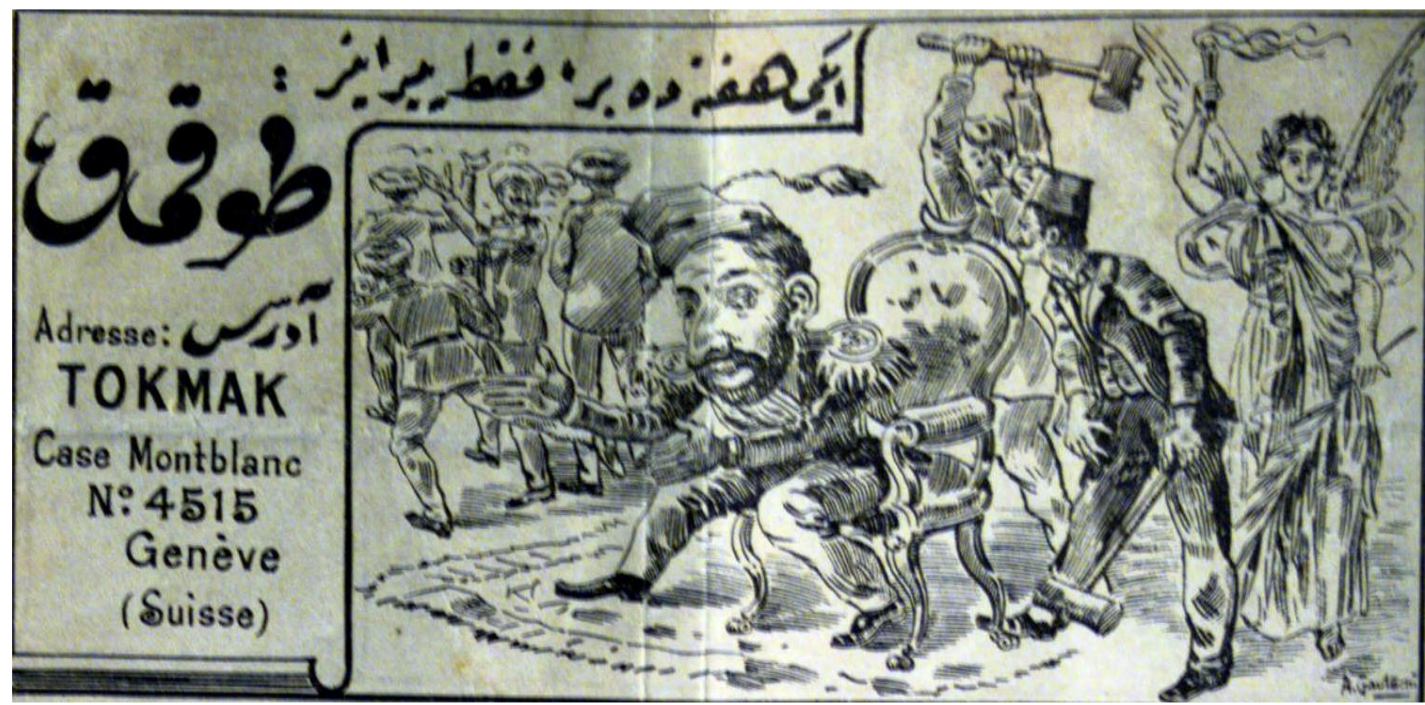

(Tokmak gazetesinin her sayısında yer alan II. Abdülhamit karikatürü)

Okuyucusuyla buluştuğu ilk sayısında, II. Abdülhamit'e yönelik sert muhalefet yapacağını bir muhavereyle duyuran gazete, amaçlarını sıraladığı bu sunuş yazısından sonra, okuyucusuna hitap eden satırlarına devam eder. Gazetenin iki haftada bir yayınlanacağının haberinin verildiği ve II. Abdülhamit'ten "Yezîd-i ekber" diye son derece çirkin bir şekilde bahsedilen bu bölümde kendilerinden mizah beklenilmemesi ifade edilse de gazetelerinin bir mizah gazetesi olduğu hatırlatılır.

Azîz vatandaşlar! Şu ufak mükâlemeden (Tokmak)ın maksadını, merâmını anlamışsınızdır. Maamâ-fîh biraz daha îzâh edelim:

(İntikâm)ın söyleyemediğini, vuramadığını (Tokmak) söyleyecek, vuracaktır. (Tokmak)tan bir lisân-1 istihzâ, bir lisân-1 mizâh, bir lisân-1 herze-furûş beklemek, boş bir bekleyiştir. Onun lisânını bir edîb-i muhteremin hâtırda kalan (hüngür hüngür gülmek) sözü pek vâzıh bir sûrette tefsîr eder. Hâsıl1 (Tokmak) Yezîd-i ekberin bütün serâ'irini, musavver, muharrer bir tarz-ı nâ-şekîbâne ve belki bir üslûb-1 
lâkaydânede arz edecektir. Böyle olmakla beraber (Tokmak) yine mizâh bir gazetedir. (Sayı 1, 1 Mart 1901)

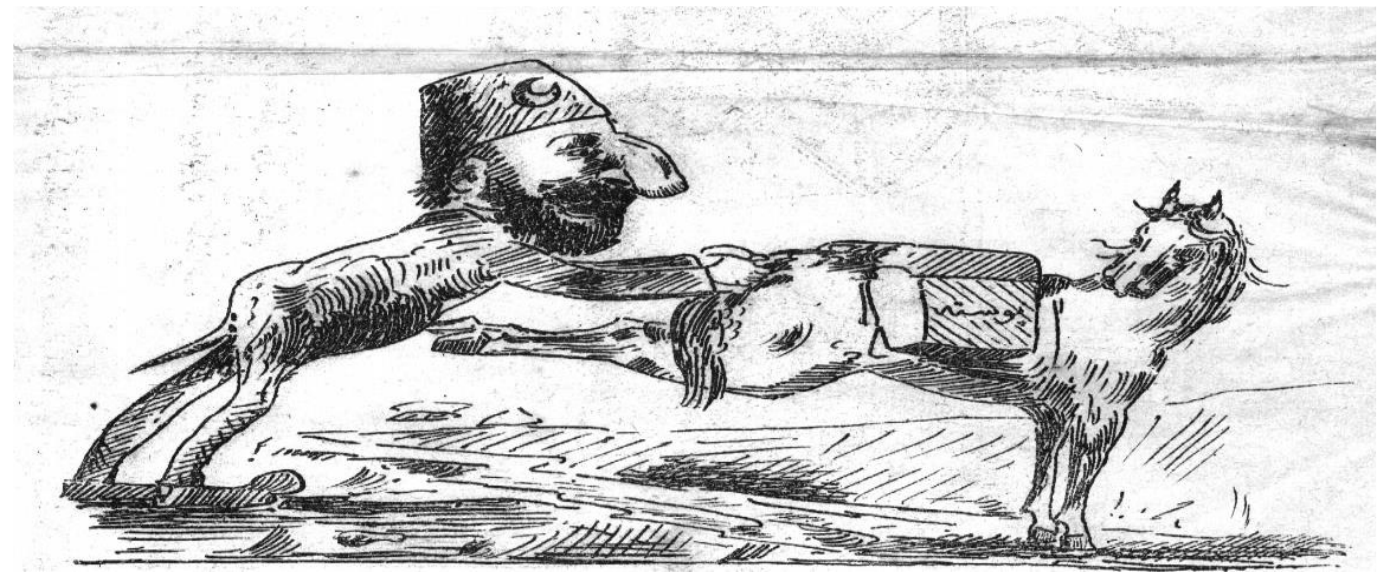

(Tokmak, Sayl 5, 15 Haziran 1901)

II. Abdülhamit’i konu edinen karikatürlere sıkl1kla yer veren gazetede, Osmanlı sultanı şiddet içeren ifadelerle hedef alınır. Ölçüsüz bir üslupla intikam ve nefret duyguların öne çıkarıldığı anlatımda, mizah unsurlarından söz etmek imkânsızdır. Nefret dolu bir şiir örneği:

Saldırdın sağa sola / Var mezârında hortla! / Hırladın ya yıllarla / Var mezârında hortla! /Âkıbet kan olacak / Durmasın insin (Tokmak) / Geber, hâin, yumurcak / Var mezârında hortla! / Şakîyi serdâr ettin / Acabâ ne kâr ettin / Dünyâyı murdâr ettin / Var mezârında hortla! / Göründü hazîne dibi / Yedin nice edîbi / Deccal eşegi gibi / Var mezârında hortla! / Yardağısın düşmenin / Halkı râhat koymadın / Dalamaya doymadın / Var mezârında hortla! /Gece gündüz kan kusar / Susarsa kana susar / Buna karşı kim susar? / Var mezârında hortla! / Çıyan gibi cırlama / Geber, kuduz hırlama / Al! Hakkındır bu kama / Var mezârında hortla! (Sayı 2, 15 Mart 1901).

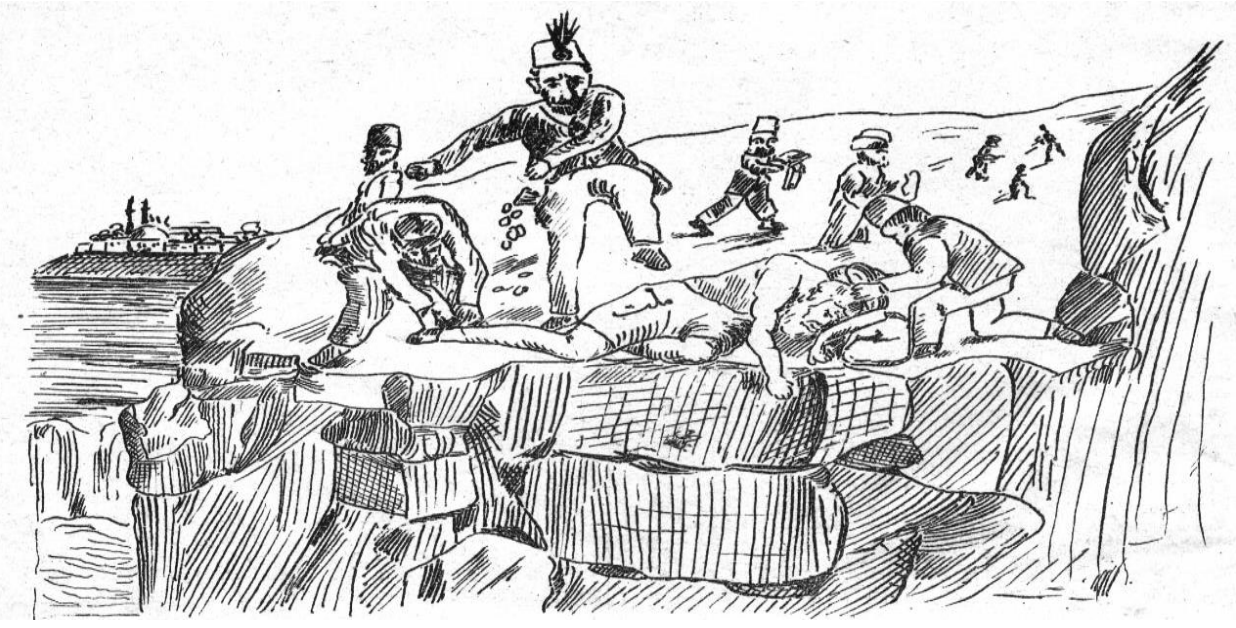

(Tokmak, Sayl 5, 15 Haziran 1901) 
Gazete II. Abdülhamit'e yönelik muhalefetin sertleşmesini ve ihtilalci bir kimliğe bürünmesini arzular. Bu doğrultuda her firsat, eyleme dönüştürülmeye çalışılır. "Bayram" başlıklı yazıda Osmanlı sultanına ağır hakaretlere devam edilerek, onu devirmek için açıkça çağrıda bulunulur:

Ey millet, millet!

Bu bayramı da kara geçirdik diye kederlendiniz mi? Bilakis müteselli olalım. Sevinelim! Çünki başımızdaki kara belâ pek yakında cehennemdeki kara kardaşlarına kavuşacak.

Ben, bunu düşünerek iki haftada bir beyn-i hümâyûna indikçe bilseniz ne kadar seviniyorum. Hâlbuki beni kendisine musallat eden siz değil misiniz, o hâlde sevinç size âiddir.

Veriniz ellerinizi, bayramlaşalım! Ve o cehennem kütügüne daha kuvvetli inelim!. (Sayı 3, 1 Nisan 1901)

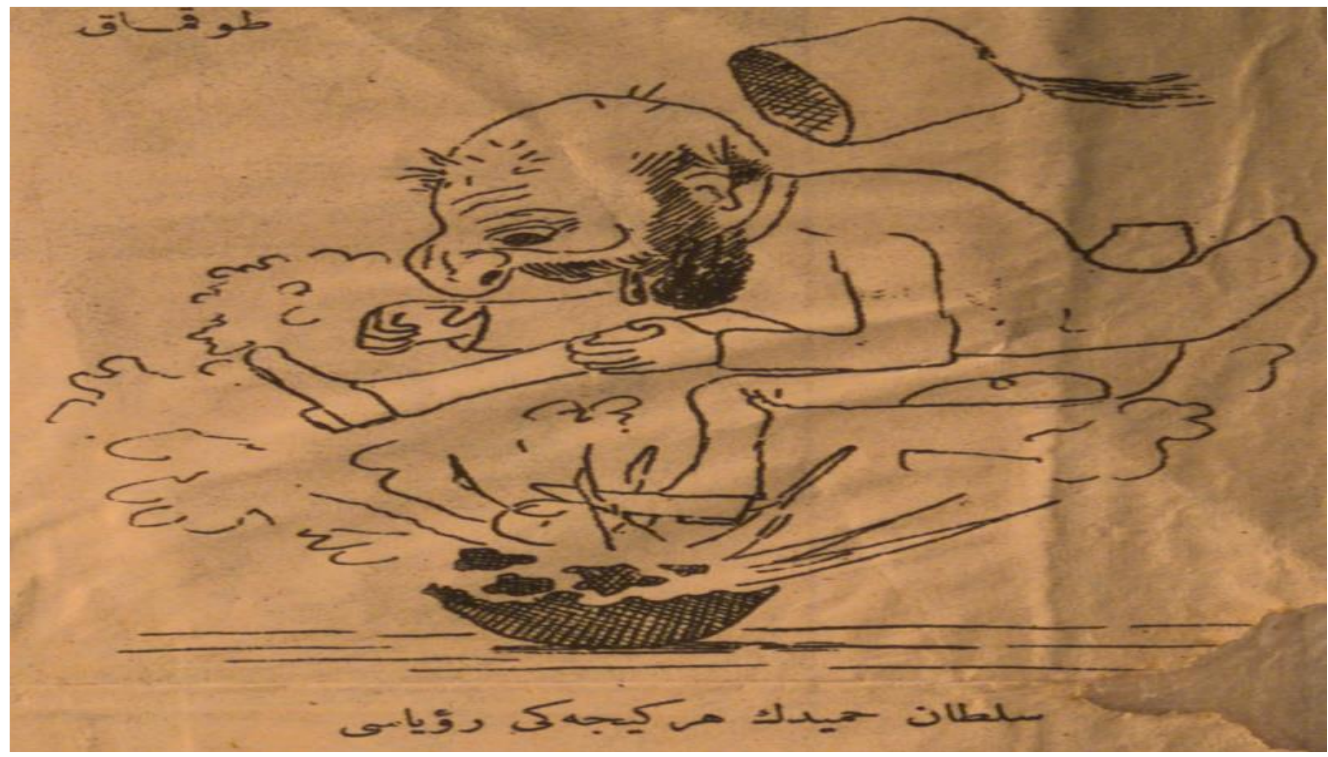

(Tokmak, Sayl 4, 25 Nisan 1901)

Yayımladığı bütün sayılarında II. Abdülhamit'i hedef alan gazetenin beşinci sayısında "Körler memleketinde yek-çeşmler Padişah olurmuş" (Sayı 5, 15 Haziran 1901) cümlesi, gazetede yayımlanan son ifade olur. Böylelikle hakaretin, kin ve öfkenin mizahın önüne geçtiği gazete, beş sayılık kısa ömrünü tamamlamış olur. Ancak gazetenin içeriği kadar kapanma süreci de oldukça dikkat çekicidir.

Cenevre'de yayımlanan kısa ömürlü gazetelerin belli pazarlıklar ve hükûmetten para sızdırmak amacıyla çıktığı görülür (Göçmen, 1995, s. 250). Bu noktada kısa ömürlü bir mizah 
gazetesi olan Tokmak da, bir pazarlık yayını olma izlenimini verir. II. Abdülhamit'i betimleyen karikatürlere son sayılara doğru ağırlık vermesi ve pazarlıklar sonucu yayın hayatını sonlandırması, gazetenin yayıma başlamadan önce pazarlık gazetesi olarak tasarlanmış olabileceği düşüncesini kuvvetlendirir.

Tokmak gazetesinin yayımlandığı dönem, Jön Türkler arasında oldukça sert siyasal çatışmaların ortaya çıktığı yıllara rastlar. Zaten ülke dışındaki Jön Türkler hiçbir zaman kalabalık ve türdeş bir kitle olmayı başaramamışlar ve sürekli anlaşmazlıklarla birbirlerinden ayrılmışlardır. II. Abdülhamit de bu rahatsız kitleyi daha da bölmek ve ülke içine çekmek için tüm önlemleri almıştır (Tunaya, 2011, s. 52). Tokmak gazetesinin yayın hayatını sonlandırma süreci, Jön Türklerin hem kendi içlerindeki çatışmaları hem de Osmanlı yönetiminin onları bölme çabalarını göstermesi bakımından dikkat çekicidir.

Cenevre'de faaliyet gösteren Jön Türklerin yayınları, kuşkusuz İstanbul'da derin rahatsızlık uyandırır. "Hayli zamandan beri Cenevre'nin hazele için merkezi fesad ve melanet ittihaz olunduğu mâlumdur” (Kuran, 2000, s. 63) ifadesini sarf eden Yıldız Sarayı, bu yayınları durdurmanın yollarını arar. II. Abdülhamit'i doğrudan hedef alan ve bir ihtilal hazırlığı yapan gazete ve dergilerin yayınlarının durdurulması için hükûmetler nezdinde hukuki girişimlerde bulunulur. Ancak İsviçre'nin liberal yasaları buna izin vermez. Cenevre'nin tavrı bu yayınların yasaklanması konusunda son derece katıdır: "Kantonlardan hiçbirinin yasaları federal anayasada güvence altına alınmış olan basın özgürlüğünü böyle ciddi bir şekilde kısıtlayamaz” (Kieser, 2008, s. 51). Böylelikle Yıldız Sarayı gazetelerin yayımlanmasının durdurulması yönündeki diplomatik ve hukuki çabaları sonuç vermeyince çareyi muhaliflerle pazarlık etmekte bulur.

Tokmak gazetesi yayımını sürdürürken şiddet yanlısı Cenevre örgütü arasında iç sorunlar baş gösterir. Tunalı Hilmi'nin örgütle ilişkisi kesildikten sonra İttihat ve Terakki merkezi İshak Sükûti ve Âkil Muhtar aracılığıyla örgütle temas kurmaya çalışır. Âkil Muhtar bu radikal örgütü ele geçirerek Saray ile yeni bir pazarlığa girişmeyi hedefler ancak başarılı olamaz. Çünkü örgüt Tokmak gazetesini bir pazarlık sonucu üç bin frank karşılığında sattıktan sonra kendi faaliyetlerini sürdürmeye devam eder (Hanioğlu, 1989, s. 180). Cenevre'deki icraatçı grubun Tokmak'1 satması, gazetelerini kapatmaları anlamına gelir. II. Abdülhamit'e yönelik sert bir muhalefet sergileyen ve mizah gazetesi olmasından çok pazarlık gazetesi kimliğiyle öne çıkan bu örgüt gazetesi, böylelikle beşinci sayısının ardından yayın hayatına son verir. 
Tokmak gazetesinin kapanma süreci, Jön Türkler arasındaki düşünce farklılıklarını göstermesi açısından önemlidir. Ancak dikkat çeken bir başka husus ise, fikir ayrılığına düşen Jön Türklerin, Saray ile pazarlık yapabilmek için adeta birbirleriyle yarışmalarıdır. Bu yönüyle Tokmak'ın yayınını sonlandırma aşamasındaki gelişmeler, basının kimi kez menfaat temini aracına dönüştüğünün de göstergesidir.

\section{Sonuç:}

II. Abdülhamit döneminde Meşrutiyet yanlısı düşünceler etrafında bir araya gelen Jön Türklerin ülke dışında basın faaliyetlerine girişmeleri, edebiyat ve basın tarihi açısından dikkat çekici veriler taşır. Ortak tutumları II. Abdülhamit'e muhalefet olan Kahire, Paris ve Cenevre gibi merkezlerde örgütlenen Jön Türkler, çıkardıkları siyasal içerikli mizah gazeteleriyle de etkili olmaya çalışırlar.

Cenevre Jön Türklerinin yayımladığı kısa ömürlü Tokmak gazetesi, yurt içinde yasaklanmasının ardından ülke dışına çıkan mizah basınını örnekleyen yayınlardan biridir. Jön Türklerin Cenevre'deki icraatçı / ihtilalci kanadının yayını olan Tokmak, sert üslubuyla dikkat çeker. Gazete, gerek şiddet çağrısı yaptığı yazılarla gerekse ağır hakaret içeren II. Abdülhamit karikatürleriyle ilgi uyandırmaya çalışır. Bir mizah gazetesinden beklenebilecek güldürme ve eğlendirme işlevinin yerine şiddet söylemini benimseyen gazetenin önemli özelliği ise pazarlık gazetesi olmasıdır. Yayın hayatını pazarlıkla sonlandıran gazete bu yönüyle ülke dışındaki Jön Türklerin kimi kez Osmanlı yönetiminden baskı ve şantaj yoluyla para alabilmek için basın faaliyetlerine yöneldiğini de gösterir.

Ülke dışında varlık gösteren II. Abdülhamit dönemi muhalif basının bir yansıması olarak değerlendirilebilecek Tokmak gazetesi, içeriğiyle ve yayımlanma sürecinde meydana gelen gelişmelerle dönemin siyasal çalkantılarını gözler önüne serer. Etkili bir ifade aracı olan mizahın zaman zaman pek de masum sayılamayacak bir çehreye büründüğünü göstermesi de Tokmak'1n öne çıkan özelliğidir.

\section{Kaynaklar}

Akşin, S. (2014). Jön Türkler ve ittihat ve terakki. Ankara: İmge Kitabevi.

Altın, H. (2014). II. meșrutiyet devri osmanlı mizah basını. Ankara: Grafiker Yayınları.

Armağan, M. (2006). Tanzimat'tan sonra mizah ve hiciv, Türk edebiyatı tarihi. İstanbul: Kültür ve Turizm Bakanlığı Yayınları, 327-343. 
Bilgegil, K. (1970). Ziyâ paşa üzerinde bir araştırma. Erzurum: Atatürk Üniversitesi Basımevi.

Bilgegil, K. (1976). Yakın çă̆ Türk kültür ve edebiyatı üzerinde araştırmalar ı yeni Osmanlılar. Ankara: Atatürk Üniversitesi Yayınları.

Budak, A. (2014). Osmanl modernleşmesi gazetecilik ve edebiyat. İstanbul: Bilge Kültür Sanat.

Göçmen, M. (1995). İsviçre'de jöntürk basını ve Türk siyasal hayatına etkileri. İstanbul: Kitabevi.

Hanioğlu, Ş. (1989). Bir siyasal örgüt olarak osmanlı ittihad ve terakki cemiyeti ve jön Türklük (1889-1902). İstanbul: İletişim Yayınları.

Kieser, H. L. (2008), Türklüğe ihtida 1870-1939 İsviçre'sinde yeni Türkiye'nin öncüleri. İstanbul: İletişim Yayınları.

Koloğlu, O. (2005). Türkiye karikatür tarihi. İstanbul: Bileşim Yayınevi.

Kuran, A. B. (2000). İnkılap tarihimiz ve jön Türkler. İstanbul: Kaynak Yayınları.

Mardin, Ş. (2002). Jön Türkerin siyasî fikirleri 1895-1908. İletişim Yayınları: İstanbul.

Şapolyo, E. B. (1971). Türk gazetecilik tarihi ve her yönü ile basın. Ankara: Güven Matbaası.

Tanpınar, A. H. (2006). XIX. Asır Türk edebiyatı tarihi. İstanbul: YKY.

Tunaya, T. Z. (2011). Türkiye'de siyasal partiler, ikinci meşrutiyet dönemi. İstanbul: İletişim yayınları.

Ulusoy N. B. (2013). Osmanlı'da muhalif basının doğuşu. İstanbul: Yeditepe Yayınevi. 